\title{
PENERAPAN RELAKSASI ATENSI UNTUK MENINGKATKAN KONSENTRASI BELAJAR PADA SISWA SMK
}

\author{
Olievia Prabandini Mulyana, Umi Anugerah Izzati, dan Diana Rahmasari \\ Program Studi Psikologi Universitas Negeri Surabaya \\ e-mail:
}

\begin{abstract}
The objectives of this research is to examine the effectiveness of attentive relaxation to increase the concentration among students of Vocational High School. Attentive relaxation applied in this research is a relaxation technique with focus on the enhancement of visual sense sensitivity. This attentive relaxation program is based on Robert H.McKim's theory with three basic phases, which are loosening up, letting go, and going to close. This research was an experiment which apply pre-test and post-test group design. The subject in this research were 60 Vocational High School students consist of 30 students in experimental group and 30 students in control group. This research conducted in Vocational High School Wachid Hasyim Surabaya. The experiment group was given the treatment of attentive relaxation, while the control group was left without treatment. Army alpha test was used to measure learning concentration. The army alpha test was administered to both experiment group and control group in pre-test and post-test conditions. The result found that attentive relaxation increase the learning concentration among Vocational High School students. This can be seen from the increase in learning concentration scores of students in experimental group between before and after the attentive relaxation treatment was given. Attentive relaxation contributes $23,3 \%$ in increasing the learning concentration of Vocational High School students.
\end{abstract}

Keywords : Learning concentration, attentive relaxation.

\begin{abstract}
Abstrak: Penelitian ini bertujuan untuk mengetahui pengaruh relaksasi atensi dalam meningkatkan konsentrasi belajar pada siswa SMK. Relaksasi atensi yang digunakan dalam penelitian ini merupakan sebuah teknik relaksasi yang lebih menekankan pada peningkatan kepekaan indera visual. Program Relaksasi Atensi ini didasarkan pada teori relaksasi atensi dari Robert H. McKim yang dengan tiga tahapan dasar, yaitu loosening up (peregangan), letting go (pembebasan ketegangan), going to close (pendekatan masalah). Jenis penelitian yang digunakan dalam penelitian ini adalah penelitian eksperimental, dengan menggunakan pre-test and post-test group design. Subjek pada penelitian ini merupakan siswa SMK yang berjumlah 60 orang yang terdiri dari 30 orang dalam kelompok eksperimen dan 30 orang dalam kelompok kontrol. Penelitian ini dilaksanakan di SMK Wachid Hasyim Surabaya. Pada kelompok eksperimen akan diberi perlakuan berupa relaksasi atensi, sedangkan pada kelompok kontrol yang tidak diberi perlakuan. Untuk mengukur konsentrasi belajar digunakan tes army alpha. Tes army alpha diberikan kepada kelompok eksperimen dan kelompok kontrol pada saat pre-test dan post-test. Relaksasi Atensi dapat meningkatkan konsentrasi belajar pada siswa SMK. Hal ini ditunjukkan dengan adanya perbedaan konsentrasi belajar antara sebelum dan sesudah dilakukan relaksasi atensi. Kelompok eksperimen menunjukkan peningkatan konsentrasi belajar setelah diberi perlakuan relaksasi atens.
\end{abstract}

Kata kunci : Konsentrasi Belajar, Relaksasi Atensi.

Setiap pelajar dalam kesehariannya di sekolah akan menjumpai berbagai materi yang menuntut mereka untuk berpikir secara kompleks maupun berpikir secara visual, tidak terkecuali dengan pelajar Sekolah Menengah Kejuruan (SMK). Pada sekolah
SMK mereka memiliki materi pelajaran yang lebih kompleks dikarenakan tujuan dari pendidikan mereka adalah lulusan yang mampu dan siap bersaing di dunia kerja. Oleh karena itu, orientasi pelajaran yang diberikan kepada siswa SMK bisa dikatakan tidak sama 
dengan materi-materi pelajaran yang diberikan kepada siswa-siswa selain SMK.

Kemampuan berpikir visual sangat berguna bagi aktivitas manusia, begitu pula bagi bagi pelajar (Douglas, 1996). Bagi pelajar di sekolah, dalam kesehariannya mereka akan menjumpai materi-materi pelajaran yang menuntut mereka untuk berpikir secara visual, contohnya penggunaan diagram statistik, rancangan praktikum pelajaran komputer, atau soal-soal mekanik dan lain sebagainya. Pelajaran-pelajaran tersebut akan dapat terselesaikan dengan baik ketika mereka mampu berpikir secara visual. Sedangkan untuk berpikir yang berkaitan dengan mengingat teori-teori dari materi pelajaran mereka, para siswa membutuhkan kemampuan berkonsentrasi yang baik agar mereka mampu memahami dan mengingat materi-materi pelajaran tersebut (Nasution, 2005). Pada kenyataannya masih banyak ditemui siswa-siswa yang sering mengalami kesulitan untuk berkonsentrasi jika dihadapkan pada materi-materi pelajaran yang lebih kompleks, misalnya berhitung, menghafal, dan sebagainya (Hakim, 2001) .

Berdasarkan ilustrasi di atas maka dapat diketahui dengan jelas faktor-faktor apa saja yang mempengaruhi kemampuan berpikir visual individu. Menurut McKim (dalam Hasan, dkk., 2000), pikiran visual individu dipengaruhi oleh dua hal, yaitu sisi internal dan eksternal individu yang sedang berpikir. Sisi eksternal dapat berupa faktor materi dan faktor lingkungan. Materi dapat berupa alatalat atau benda yang kita hadapi, sedangkan lingkungan dapat berbentuk ruangan. Sisi internal yang mempengaruhi pikiran visual kita adalah kemampuan kita mengorganisasikan perhatian dengan relaks.

Konsentrasi atau mengorganisasikan perhatian sangat diperlukan dalam menghadapi masalah sehari-hari. Kompleksnya permasalahan yang dihadapi oleh orangorang modern, dimana tuntutan pemenuhan kebutuhan semakin keras didukung dengan lingkungan yang sering menimbulkan ketegangan, membuat orang-orang modern kurang mampu mengadakan konsentrasi terhadap suatu permasalahan (Fromm, 1988). Hal ini dikarenakan banyak hal yang mereka rasakan sehingga konsentrasi mereka selalu terpecah dengan ketegangan yang mereka ciptakan sendiri.

Ketidakmampuan melakukan relaksasi menyebabkan individu kesulitan untuk memfokuskan perhatian. Apa lagi ditambah dengan pikiran bahwa setiap distraktor (hal yang tidak penting) dianggap sebagai hal yang berpotensi dan penting sehingga patut diperhitungkan (McKim, dalam Hasan, dkk., 2000). Konsentrasi terhadap sebuah masalah selalu akan mengakibatkan kaitan dengan masalah lain yang tidak ada hubungannya dengan masalah tersebut sehingga jalan penyelesaiannya menjadi semakin jauh.

Brown (1980) mencatat bahwa orangorang yang memiliki rasa nyaman dan tidak merasakan kekhawatiran adalah orang-orang yang mampu bekerja secara konsisten tanpa merasakan kelebihan beban, mempunyai kesensitifan akan kebutuhan untuk melakukan istirahat, dan orang-orang yang tidak pernah bosan belajar bagaimana cara yang baik melakukan relaksasi. Selama ini program-program relaksasi dikenakan pada individu untuk mengendurkan urat syaraf yang tegang, meredahkan pikiran, mengurangi stres, dan berusaha memulihkan energi yang telah dikeluarkan dalam beraktivitas.

Relaksasi merupakan sebuah teknik untuk merelaksasikan fisik maupun batin (pikiran). Teori ini seharusnya sudah diketahui oleh banyak orang. Bagi yang sehat, relaksasi berfungsi untuk menjaga kesehatan, meningkatkan stamina, dan memulihkan daya ingat (menghindari kepikunan). Sedangkan bagi yang sedang sakit teknik ini mampu mengurangi rasa sakit dan secara berangsur 
akan mendukung pemulihan kondisi kesehatan. Teknik relaksasi berorientasi pada kesegaran pikiran yang stres akibat tekanan dari aktivitas sehari-hari atau dari dampak beban penyakit. Pada kondisi seperti itu harus diupayakan untuk penyegaran. Gambaran mudahnya adalah seperti saat kita telah merasa keberatan memikul suatu beban, maka luangkan waktu sejenak untuk beristirahat. Relaksasi adalah mengistirahatkan fisik dan pikiran dengan kondisi kesadaran penuh.

Untuk mengatasi masalah ini peneliti menyusun sebuah program relaksasi yang dapat diterapkan oleh siswa untuk meningkatkan konsentrasi mereka dalam proses belajar mengajar di kelas. Peneliti memberi nama program ini Relaksasi Atensi karena program ini disusun dengan pendekatan ketenangan perhatian (attention) siswa melalui relaksasi yang sesuai dengan teori Robert McKim (dalam Hasan, dkk., 2000).

Manusia akan banyak mengeluarkan energi ketika beraktivitas dan untuk mengembalikan kekuatan agar bisa kembali beraktivitas manusia harus memperbaharui energi yang telah dihabiskannya sehingga keadaan tegang, lemah, atau stres dapat dikurangi. Cara-cara yang biasa dilakukan adalah dengan makan, minum, istirahat, atau melakukan relaksasi. Relaksasi adalah sebuah teknik pereduksian kecemasan, stres, dan tegangan yang dialami oleh individu. Relaksasi memuat peregangan, membiarkan berlaku dan pergi tidur. Prinsip utama dari relaksasi adalah seakan-akan memudahkan segala urusan (make it seem easy) dan mengurangi ketegangan yang tidak berguna (relaxing irrelevan tension).

Adapun dengan relaksasi atensi, McKim (dalam Hasan, dkk., 2000) menyatakan bahwa relaksasi atensi diartikan sebagai satu perenggangan dari perhatian kita. Dari term yang digunakan seakan dua kata itu berlawanan. Atensi menuntut untuk konsentrasi tetapi relaksasi malah mengurangi konsentrasi. Lebih lanjut menurut McKim, dua term itu ibarat sebuah keping mata uang. Masing-masing adalah sisi yang berlawanan tetapi berguna dalam satu penyelesaian masalah, dalam hal ini adalah menurunkan ketegangan yang dialami individu yang menurunkan konsentrasi dalam belajar.

Terdapat berbagai macam metode dan tujuan relaksasi yang memiliki perbedaan dalam penyajian dan pelaksanaannya masingmasing, namun relaksasi memiliki dasar filosofi yang sama, yaitu peredaan ketegangan yang dialami individu. Demikian juga dengan relaksasi atensi, dasar dari relaksasi atensi adalah ketenangan individu yang nantinya akan mempengaruhi keoptimalan kinerja saraf indera penglihatan. Relaksasi atensi adalah relaksasi yang lebih menekankan pada peningkatan kepekaan indera visual manusia. Dasar dari relaksasi atensi sama dengan relaksasi pada umumnya yaitu peredaan ketegangan dan kecemasan. Individu yang mengalami ketegangan yang tidak terkontrol akan mempengaruhi persepsi indera penglihatan terhadap suatu obyek atau benda.

Relaksasi atensi membawa manfaat pada aktivitas yang dilakukan manusia, yaitu berguna dalam aktivitas berpikir secara umum, dalam proses kreatif, dan pada pemahaman visual. Relaksasi atensi juga erat kaitannya dengan meningkatkan kemampuan konsentrasi. Dengan memaksimalkan konsentrasi melalui relaksasi atensi, semua gangguan dalam bentuk titik atau sudut yang tidak relevan dapat disingkirkan dari perhatian.

Relaksasi atensi sendiri dibangun dengan tiga tahapan dasar, yaitu loosening up (peregangan), letting go (pembebasan ketegangan), dan going to close (pendekatan masalah). Pada loosening up (peregangan) relaksasi memiliki pendekatan pada peregangan otot-otot tubuh yang mengalami 
ketegangan sehingga dengan menjadi rileks otot yang tegang dapat kembali normal. Dalam relaksasi posisi yang diambil adalah kerenggangan seluruh anggota tubuh. Pada tahap letting go (pembebasan ketegangan) individu membebaskan keteganganketegangan yang ada dengan bebas dan menyadari bahwa ketegangan-ketegangan itu telah lepas. Pikiran dan anggota tubuh mengalami ketegangan yang menekan. Sedangkan pada tahapan going to close (pendekatan masalah), relaksasi dilakukan dengan membuka kesadaran dan memusatkan perhatian hanya pada satu perhatian dengan mengabaikan masalah yang lain.

Sebagai pelajar, perhatian atau konsentrasi yang harus diutamakan adalah pada proses belajar dan mengabaikan masalah yang lain (konsentrasi belajar). Konsentrasi belajar berasal dari dua kata, yaitu konsentrasi dan belajar. Slameto (2003: 86) mengartikan konsentrasi sebagai "pemusatan pikiran terhadap suatu hal dengan mengesampingkan semua hal lainnya yang tidak berhubungan." Sedangkan konsentrasi belajar adalah pemusatan perhatian dalam pelajaran. Ciriciri siswa yang dapat berkonsentrasi belajar tampak pada perhatiannya yang terfokus pada hal yang diterangkan guru atau pelajaran yang sedang dipelajari (Slameto, 2003).

Ciri-ciri siswa yang dapat berkonsentrasi belajar juga berkaitan dengan perilaku belajar yang meliputi perilaku kognitif, perilaku afektif, dan perilaku psikomotor (Dimyati, 2002). Karena belajar merupakan aktivitas yang berbeda-beda pada berbagai bahan pelajaran, maka perilaku konsentrasi belajar tidak sama pada perilaku belajar tersebut. Engkoswara (dalam Tabrani, 1989) menjelaskan klasifikasi perilaku belajar yang dapat digunakan untuk mengetahui ciriciri siswa yang dapat berkonsentrasi belajar, yaitu: (1) Perilaku kognitif. Siswa yang memiliki konsentrasi belajar dapat diidentifikasi dengan kesiapan pengetahuan yang dapat segera muncul bila diperlukan, komprehensif dalam penafsiran informasi, mengaplikasikan pengetahuan yang diperoleh, dan mampu mengadakan analisis dan sintesis pengetahuan yang diperoleh; (2) Perilaku afektif. Pada perilaku ini siswa yang memiliki konsentrasi belajar dapat ditengarai dengan adanya penerimaan (tingkat perhatian tertentu), respon (keinginan untuk mereaksi bahan yang diajarkan), mengemukakan suatu pandangan atau keputusan sebagai integrasi dari suatu keyakinan, ide dan sikap seseorang; (3) Perilaku psikomotor. Siswa yang memiliki konsentrasi belajar dapat ditengarai dengan adanya gerakan anggota badan yang tepat atau sesuai dengan petunjuk guru, komunikasi non-verbal seperti ekspresi muka dan gerakan-gerakan yang penuh arti; (4) Perilaku berbahasa. Siswa yang memiliki konsentrasi belajar dapat ditengarai adanya aktivitas berbahasa yang terkoordinasi dengan baik dan benar.

Pada anak usia sekolah, prestasi belajar seorang siswa sangat dipengaruhi oleh kemampuan menyerap pelajaran yang diberikan. Kemampuan menyerap pelajaran tersebut, baik yang diperoleh karena memperhatikan apa yang diajarkan guru maupun dari hasil upaya belajar mandiri, ditentuka oleh kemampuan konsentrasi siswa.

Bagi siswa SMK, relaksasi atensi memiliki manfaat yang penting karena melalui kegiatan tersebut mereka akan lebih mampu meningkatkan konsentrasi mereka sehingga mereka akan lebih bisa memahami mata pelajaran yang diberikan guru mereka di sekolah. Dengan memahami pelajaran dengan baik, mereka akan mampu meningkatkan prestasi menjadi lebih optimal. Di samping itu, dengan relaksasi atensi mereka juga akan mendapatkan manfaat lainnya selain untuk meningkatkan konsentrasi, yaitu mereka akan mampu berpikir dengan tenang dan meningkatkan daya ingat sehingga membuat mereka mampu memecahkan berbagai 
permasalahan yang ditemui. Relaksasi atensi juga mampu mengoptimalkan proses belajar sehingga mereka tidak mudah bosan dan jenuh saat belajar dan lain-lain.

Kegiatan relaksasi atensi ini dipandang efektif dan tepat dalam meningkatkan konsentrasi siswa SMK karena dalam kegiatan tersebut mereka akan merasakan situasi yang tenang dan jauh dari rasa tegang dan tertekan. Dalam kondisi yang tenang mereka bisa lebih fokus terhadap suatu hal dengan perasaan tenang dan damai. Diharapkan dengan relaksasi atensi akan membuat pikiran menjadi lebih fresh atau segar kembali sehingga memudahkan mereka untuk mengawali hal baru dengan lebih baik, misalnya mereka bisa lebih maksimal dalam berkonsentrasi atau dalam mengingat segala hal. Relaksasi atensi erat kaitannya dengan meningkatkan kemampuan konsentrasi dan dengan memaksimalkan konsentrasi melalui relaksasi atensi, semua gangguan dalam bentuk titik atau sudut yang tidak relevan akan dapat disingkirkan dari perhatian.

\section{METODE}

Jenis penelitian yang digunakan dalam penelitian ini adalah penelitian eksperimental. Dalam penelitian ini peneliti menggunakan pre-test dan post-test. Subjek akan dibagi menjadi dua, yaitu dalam kelompok kontrol dan kelompok eksperimen. Kelompok eksperimen memperoleh perlakuan berupa Program Relaksasi Atensi. Sedangkan kelompok control tidak mendapatkan pelatihan tersebut. Sebelum dan sesudah pelatihan, subjek diukur kemampuan konsentrasinya dengan menggunakan tes kemampuan konsentrasi.

\section{Partisipan}

Subjek dalam penelitian ini adalah siswa SMK Wachid Hasyim Surabaya yang terdiri dari 60 orang yang dibagi menjadi dua kelompok. Sebanyak 30 orang dalam kelompok eksperimen dan 30 orang dalam kelompok kontrol.

\section{Prosedur}

Langkah-langkah yang dilakukan pada tahap pelaksanaan penelitian antara lain:

a) Pre-test pada kelompok eksperimen dan kelompok kontrol.

Pelaksanaan pre-test dilakukan pada subjek penelitian untuk mengetahui gambaran mengenai konsentrasi belajar pada subjek penelitian. Pre-test dilaksanakan dengan memberikan tes army alpha pada kedua kelompok, yaitu kelompok eksperimen dan kelompok kontrol.

b) Relaksasi atensi

Setelah terbentuk dua kelompok subjek penelitian, yaitu kelompok eksperimen dan kelompok kontrol, tahapan selanjutnya adalah perlakuan. Perlakuan berupa relaksasi atensi diberikan pada kelompok eksperimen, sedangkan pada kelompok kontrol tidak dikenakan perlakuan. Kelompok kontrol merupakan kelompok waiting list. Kelompok kontrol akan diberi perlakuan setelah kelompok kontrol melaksanakan post-test atau di luar prosedur penelitian sehingga pembahasan perlakuan kepada kelompok kontrol setelah post-test tidak dibahas dalam penelitian ini.

Proses pelaksanaan dalam mempersiapkan relaksasi atensi adalah dengan cara memberikan arahan kepada siswa untuk menjalankan kegiatan relaksasi atensi tersebut sebanyak 3 kali pertemuan. Kelompok eksperimen diberikan pengarahan satu kali sebelum pertemuan untuk melaksanakan pelatihan relaksasi atensi. Kelompok eksperimen diberi arahan untuk menjalankan beberapa 
tahapan kegiatan pelatihan relaksasi atensi mulai dari tahap awal sampai tahap akhir dengan arahan dan bimbingan dari peneliti sesuai dengan urutan-urutan kegiatan pelatihan relaksasi atensi yang benar. Peneliti juga memberikan bekal kepada kelompok eksperimen agar bisa memberikan stimulus dan dapat menciptakan suasana yang aktif dan kondusif dalam kegiatan pelatihan relaksasi atensi yang akan dilaksanakan.

Pada pelaksanaan relaksasi atensi ini dilakukan sebanyak tiga kali pertemuan yang dilaksanakan pada bulan Juni 2012. Pertemuan dilakukan sekali dalam seminggu, yakni setiap hari Sabtu di ruang serbaguna SMK Wachid Hasyim Surabaya dengan durasi waktu \pm 120 menit setiap pertemuan. Pelaksanaan relaksasi atensi melalui tiga tahapan dasar, yaitu loosening up (peregangan), letting go (pembebasan ketegangan), dan going to close (pendekatan masalah).

c) Post-test pada kelompok eksperimen dan kelompok kontrol

Pelaksanaan post-test diberikan pada kelompok eksperimen dan kelompok kontrol dengan memberikan tes army alpha. Post-test pada kelompok eksperimen dilakukan setelah kelompok eksperimen menerima perlakuan relaksasi atensi. Selanjutnya hasil post-test dianalisis untuk memperoleh gambaran mengenai perlakuan relaksasi atensi yang diberikan kepada kelompok eksperimen.

\section{Teknik Pengumpulan Data}

Variabel penelitian ini terdiri dari variabel bebas (relaksasi atensi) dan variabel terikat (konsentrasi belajar). Relaksasi atensi adalah sebuah teknik relaksasi yang lebih menekankan pada peningkatan kepekaan indera visual. Program Relaksasi Atensi ini didasarkan pada teori relaksasi atensi dari
Robert H. McKim yang terdiri atas tiga tahapan dasar, yaitu loosening up (peregangan), letting go (pembebasan ketegangan), dan going to close (pendekatan masalah). Konsentrasi belajar adalah pemusatan perhatian terhadap pelajaran, baik yang diajarkan guru maupun dari hasil upaya belajar mandiri. Untuk mengukur konsentrasi belajar digunakan tes army alpha.

\section{Teknik Analisis Data}

Teknik analisis data yang digunakan dalam penelitian ini adalah analisis variansi (ANAVA) repeated measure dari program komputer SPSS versi 17 untuk melihat adanya perbedaan antara kelompok eksperimen yang diberi perlakuan dengan kelompok kontrol yang tidak diberi perlakuan dan untuk melihat perbedaan pre-test dan post-test pada kelompok kontrol dan kelompok eksperimen. Sedangkan Uji-T yaitu Independent-Sample $T$ Test dan Paired-Samples T Test digunakan untuk mengetahui apakah terdapat perbedaan konsentrasi belajar pada pre-test dan post-test baik pada kelompok eksperimen maupun kelompok kontrol

\section{HASIL DAN PEMBAHASAN}

\section{Hasil}

Dari hasil analisis data diketahui bahwa skor minimal konsentrasi belajar yang dapat diperoleh subjek penelitian adalah 1 dan skor maksimalnya adalah 10 , sedangkan rerata hipotetiknya adalah 5. Skor rerata yang diperoleh pada kelompok eksperimen sebelum relaksasi atensi adalah 6,43 dengan deviasi standar $(\sigma)$ sebesar 1,906 , sedangkan rerata setelah penerapan relaksasi atensi sebesar 10,60 dengan deviasi standar $(\sigma)$ sebesar 2,472.

Dari hasil kategori, kategorisasi ini menggunakan skor empiric didasarkan pada 
distribusi normal yang dimiliki subjek penelitian. Pada kelompok kontrol prosentase subjek yang masuk pada kategori rendah (R) adalah $10 \%$ pada pre-test dan $10 \%$ pada saat post-test, dan subjek pada kategori rata-rata bawah (C-) adalah 73,33\% pada pre-test dan $70 \%$ pada saat post-test. Sedangkan subjek pada kategori rata-rata (C) adalah 16,67\% pada pre-test dan $20 \%$ pada saat post-test. Hal ini menunjukkan bahwa tidak ada perubahan yang signifikan pada saat pre-test dan posttest.

Pada kelompok eksperimen yang masuk pada kategori rendah $(\mathrm{R})$ adalah $13,33 \%$ pada pre-test dan $0 \%$ pada saat post-test dan subjek pada kategori rata-rata bawah (C-) adalah 73,33 \% pada pre-test dan 13,33\% pada saat post-test. Sedangkan subjek pada kategori rata-rata (C) adalah $10 \%$ pada pre-test dan 40 $\%$ pada saat post-test. Di samping itu, subjek pada kategori rata-rata atas $(\mathrm{C}+)$ adalah 3,33 $\%$ pada pre-test dan $46,6 \%$ pada saat post-test. Hal ini menunjukkan adanya peningkatan prosentase subjek yang memiliki kategori rata-rata $(\mathrm{C})$ dan rata-rata atas $(\mathrm{C}+)$ pada konsentrasi belajar.

Uji normalitas pertama dilakukan untuk melihat apakah ada penyimpangan frekuensi hasil penelitian dari frekuensi hipotetik. Jika tidak ada penyimpangan maka variabel yang diuji memiliki sebaran normal. Uji normalitas menggunakan teknik Kolmogorov-Smirnov dari program komputer SPSS versi 17.0. Uji normalitas dilakukan pada variabel konsentrasi belajar pada pre-test dan post-test pada masing-masing kelompok, yaitu kelompok eksperimen dan kelompok kontrol.

Hasil uji asumsi normalitas untuk pretest dan post-test pada kelompok eksperimen dan kelompok kontrol memiliki nilai Kolmogorov-Smirnov Z sebesar 1,368; 0,$992 ; 1,084$ dan 1,448 dengan $p>0,05$. Hasil ini menunjukkan bahwa frekuensi dari semua kelompok memiliki sebaran normal. Sedangkan berdasarkan analisis data melalui uji Levene's Test probabalitas $>0,05$, maka data konsentrasi belajar baik pre-test maupun post-test memiliki varian yang homogen atau data berasal dari populasi-populasi dengan varian yang sama.

Pengujian hipotesis penelitian ini mendapatkan hasil data sebagai berikut:

1) Ada perbedaan rerata konsentrasi belajar sebelum dan sesudah relaksasi atensi $(\mathrm{F}=92,005, \mathrm{p}<0,05) . \quad$ Besarnya sumbangan amatan ulangan terhadap konsentrasi belajar adalah sebesar $61,3 \%$.

2) Ada perbedaan rerata konsentrasi belajar antara kelompok eksperimen dan kelompok kontrol $(\mathrm{F}=91,005, \mathrm{p}<0,05)$. Besarnya sumbangan kelompok terhadap konsentrasi belajar adalah sebesar $51,1 \%$.

3) Ada perbedaan rerata konsentrasi belajar antara kelompok eksperimen dan kelompok kontrol dengan memperhatikan pengukuran sebelum dan sesudah relaksasi atensi $(\mathrm{F}=17,615, \mathrm{p}<0,05)$. Besarnya sumbangan interaksi kelompok dan amatan ulangan terhadap konsentrasi belajar adalah sebesar 23,3\%.

Teknik analisis statistik yang digunakan selanjutnya adalah $\mathrm{Uji}-\mathrm{T}$ yaitu Independent-Sample $T$ Test dan PairedSamples $T$ Test untuk mengetahui apakah terdapat perbedaan konsentrasi belajar pada pre-test dan post-test baik pada kelompok eksperimen maupun kelompok kontrol. Hasil analisis data menunjukkan:

1) Tidak ada perbedaan skor konsentrasi belajar pada pre-test baik pada kelompok eksperimen maupun kelompok kontrol $(\mathrm{t}=10,372, \mathrm{p}>0,05)$.

2) Ada perbedaan skor tes konsentrasi belajar antara sebelum dan sesudah perlakuan pada kelompok eksperimen $(\mathrm{t}=$ $10,456, \mathrm{p}<0,05)$.

3) Tidak ada perbedaan skor tes konsentrasi belajar antara pre-test dan post-test pada kelompok kontrol $(\mathrm{t}=0,000, \mathrm{p}>0,05)$.

4) Ada perbedaan hasil tes konsentrasi 
belajar pada saat post-test antara kelompok eksperimen dan kelompok kontrol $(\mathrm{t}=7,175, \mathrm{p}<0,05)$.

\section{Pembahasan}

Penelitian ini menggunakan model penelitian Two Independent Group Design yaitu penelitian eksperimen yang membutuhkan dua kondisi perlakuan dengan menempatkan subjek penelitian dalam dua kelompok, yaitu kelompok eksperimen dan kelompok kontrol (Mayers \& Hansen, 2002). Kelompok eksperimen dikenai perlakukan berupa relaksasi atensi sedangkan kelompok lainnya tidak dikenai perlakukan apapun karena berfungsi sebagai kelompok kontrol. Setiap subjek penelitian, baik pada kelompok eksperimen maupun kelompok kontrol, dikenai pre-test dan post-test berupa tes army alpha. Hasil pre-test dan post-test pada seluruh subjek penelitian dianalisis menggunakan Anava Amatan Ulangan.

Hasil analisis dengan Anava Amatan Ulangan menunjukkan bahwa terdapat peningkatan konsentrasi belajar setelah dilakukan relaksasi atensi $(F=17,615$, $\mathrm{p}<0,05)$. Kelompok eksperimen menunjukkan peningkatan konsentrasi belajar setelah diberi perlakuan relaksasi atensi. Hasil analisis tersebut ditunjang dengan rerata skor kelompok eksperimen yang meningkat 4,75 (pre-test $=6,43$ dan post-test $=10,60)$, dan hasil analisis Uji-T $(\mathrm{t}=-10,456, \mathrm{p}<0,05)$ juga menunjukkan ada perbedaan skor tes konsentrasi belajar antara sebelum dan sesudah perlakuan pada kelompok eksperimen. Berdasarkan pada uraian di atas maka hipotesis yang menyatakan ada pengaruh relaksasi atensi terhadap konsentrasi belajar pada siswa SMK dan relaksasi atensi dapat meningkatkan konsentrasi belajar pada siswa SMK dapat diterima.

Relaksasi atensi menunjukkan efektivitas dalam meningkatkan kemampuan konsentrasi siswa. Relaksasi atensi efektif untuk meningkatkan kemampuan konsentrasi siswa disebabkan oleh beberapa hal, di antaranya pelatihan relaksasi atensi tersebut dapat dilaksanakan dengan baik oleh siswa SMK Wachid Hasyim Surabaya yang memiliki keinginan untuk meningkatkan kemampuan konsentrasi ketika belajar sehingga akan mendapatkan pretasi belajar yang lebih baik.

Tingkat konsentrasi belajar siswa SMK Wachid Hasyim Surabaya sebelum mendapatkan relaksasi atensi (pre-test) masih tergolong pada kategori rata-rata bawah (C-) yang berarti bahwa kemampuan konsentrasi siswa SMK Wachid Hasyim Surabaya masih cenderung rendah. Setelah mendapatkan relaksasi atensi, tingkat konsentrasi belajar berada pada kategori rata-rata atas $(\mathrm{C}+)$ yang berarti bahwa konsentrasi belajar siswa sudah menunjukkan ke arah yang lebih baik. Hal ini menunjukkan bahwa kegiatan relaksasi atensi mampu meningkatkan kemampuan konsentrasi siswa ke arah peningkatan dan pengembangan yang lebih positif. Dengan demikian dapat disimpulkan bahwa kemampuan konsentrasi siswa sebelum mendapatkan relaksasi atensi dengan sesudah mendapatkan relaksasi atensi adalah berbeda dan mengalami peningkatan.

Kegiatan relaksasi atensi ini dipandang efektif dan tepat dalam meningkatkan konsentrasi siswa SMK karena dalam kegiatan tersebut mereka akan merasakan situasi yang tenang dan jauh dari rasa tegang dan tertekan sehingga mereka mampu fokus terhadap suatu hal dengan kondisi tenang dan damai. Diharapkan dengan relaksasi atensi akan membuat pikiran menjadi lebih fresh atau segar kembali sehingga memudahkan mereka untuk mengawali hal baru dengan lebih baik (Winger, 2004). Relaksasi atensi erat kaitannya dengan meningkatkan kemampuan konsentrasi. Dengan 
memaksimalkan konsentrasi melalui relaksasi atensi, semua gangguan dalam bentuk titik atau sudut yang tidak relevan akan dapat disingkirkan dari perhatian.

Bagi siswa SMK, relaksasi atensi memiliki manfaat yang penting karena melalui kegiatan tersebut mereka akan lebih mampu meningkatkan konsentrasi sehingga mereka lebih bisa memahami mata pelajaran yang diberikan guru mereka di sekolah. Dengan memahami pelajaran dengan baik mereka akan mampu meningkatkan prestasi menjadi lebih optimal (Dahar, 1999). Di samping itu, dengan relaksasi atensi mereka juga akan mendapatkan manfaat lainnya selain untuk meningkatkan konsentrasi, mereka akan mampu berpikir dengan tenang dan meningkatkan daya ingatnya sehingga membuat mereka akan mampu memecahkan berbagai permasalahan yang ditemui. Relaksasi atensi juga mampu mengoptimalkan belajar mereka sehingga mereka tidak mudah bosan dan jenuh saat belajar

Analisis untuk sumbangan yang efektif didapatkan melalui eta kuadrat yaitu berapa persen prosentase variasi variabel independen yang diakibatkan oleh perlakuan. Pada penelitian ini menunjukkan pengaruh relaksasi atensi mampu meningkatkan konsentrasi belajar sebesar 23,3\%. Dengan kata lain, relaksasi atensi dapat meningkatkan konsentrasi belajar sebesar $23,3 \%$, sedangkan $76,7 \%$ peningkatan konsentrasi belajar terjadi karena variabel lain.

\section{SIMPULAN DAN SARAN}

Berdasarkan hasil analisis data dan pembahasan hasil penelitian maka dapat ditarik kesimpulan bahwa relaksasi atensi dapat meningkatkan konsentrasi belajar pada siswa SMK. Hal itu ditunjukkan dengan adanya perbedaan konsentrasi belajar antara sebelum dan sesudah dilakukan relaksasi atensi. Kelompok eksperimen menunjukkan peningkatan konsentrasi belajar setelah diberi perlakuan relaksasi atensi. Relaksasi atensi cukup efektif dalam meningkatkan konsentrasi belajar siswa SMK. Relaksasi atensi memberikan sumbangan sebesar 23,3 $\%$ dalam meningkatkan konsentrasi belajar pada siswa SMK.

Penelitian ini membuktikan bahwa individu yang banyak memperoleh manfaat meningkatkan konsentrasi belajar adalah mereka yang berpartisipasi aktif dalam kegiatan relaksasi atensi. Oleh karena itu, pada pelaksanaan relaksasi atensi perlu ditekankan bahwa keberhasilan dalam meningkatkan konsentrasi belajar ditentukan oleh dirinya sendiri. Untuk mendukung kesempurnaan penelitian ini perlu dilakukan penelitian lebih lanjut tentang peningkatan konsentrasi belajar dengan memperhatikan atau mengontrol faktor-faktor lain yang dapat mempengaruhi konsentrasi belajar, misalnya pola asuh, lingkungan keluarga, dan status sosial ekonomi.

\section{DAFTAR PUSTAKA}

Brown, A. L. (1980). Metacognitive development and reading. In R. J. Spiro, B. C. Bruce \& W. Brewer (Eds.). Theoretical issues in reading comprehension (pp. 453-481).
Hillsdale, NJ: Lawrence Erlbaum Associates.

Dahar, R.W. (1999). Teori-Teori Belajar. Jakarta: Erlangga.

Dimyati. (2002). Belajar dan Pembelajaran. 
Jakarta: Rineka Cipta.

Douglas, J. (1996). Daya Ingat Super: Program Kilat Penyempurnaan Daya Ingat. Jakarta: Pustaka Dela Pratasa.

Fromm, E. (1988). Manusia Bagi Dirinya: Suatu Telaah Psikologis-Filosofis Tentang Tingkah Laku Manusia Modern. (Terjemahan). Jakarta: Akademika.

Hakim, T. (2001). Belajar Secara Efektif. Jakarta: Puspa Swara.

Hasan M, Diah U., Handayani, S., Diana, S. (2000). Metode Relaksasi Atensi untuk Meningkatkan Kemampuan Pemahaman Ruang Bidang pada Pelajar Sekolah Menengah Kejuruan (SMK). Buletin Penalaran Mahasiswa, IX(1).
Mayers, A., Hansen, C.H. (2002). Experimental Psychology. Fifth Edition. New York: Adworth Group dan Devision of Thomson Learning Inc.

Nasution, S. (2005). Berbagai Pendekatan dalam Proses Belajar dan Mengajar. Bandung: Bina Aksara.

Rusyan, A. T. (1999). Pendekatan dalam Proses Belajar Mengajar. Bandung: CV Remaja Kenanga.

Slameto. (2003). Belajar dan Faktor-Faktor yang Mempengaruhinya. Jakarta: Rineka Cipta.

Winger. (2004). Beyond Teaching \& Learning: Memadukan Quantum Teaching \& Learning. Bandung: Nuansa. 